but it makes practically no effort to assess how the advent of online sources might alter organizational structures or management methods.

After having been presented with such simple fare throughout most of the book, one arrives at the final chapter, entitled "The Challenge," hungry for substance. Once again, however, very little substance is served up. Instead of an action agenda and some original conclusions, the reader receives yet another recitation of the drawbacks of paper publications, followed by a list of "major changes" that one can expect to characterize library services in the online age (e.g., "assembling local collections" will become "less important," and "local storage may be desirable but is nolonger necessary."). And thus the book endsnoting in conclusion that "[computers], networks, and electronic documents" will provide library services in the future with "interesting possibilities."

This book is very disappointing for many reasons, not the least of which is that it gives the impression of having been written five or ten years ago, before many of the nation's research library catalogs were accessible on the Internet, before such systems as NOTIS MDAS permitted libraries to mount online bibliographies that link bibliographical citations to local holdings, and well before most of what is presented and re-presented in this book had been examined in much more developed form throughout the library literature. The book also gives the clear impression, to me at least, that it was written very quickly, as if the author simply sat down and wrote up what he knew, drawing heavily and primarily on his own previous publications, without taking the time to refine or update his views. There is in fact very little, if anything, in this book that one would not expect to hear in the first few lectures of any introductory library school course. One also encounters statements like "[research] ... has shown that ..." (p.36), or "studies have shown that ..." (p.49), without any accompanying information as to where these studies were published or this research was conducted; it is as if the author did not want to take the time to look up the documentation.

Redesigning Library Services can certainly be read as a basic introduction to some of the key issues facing library services, and there can be no doubt that the book is sincerely written and well intentioned. However, it is also shortsighted, outdated, hyperbolic, and repetitive. It is especially regrettable that the American Library Association should have seen fit to publish such a book with such a title, giving as it does the impression that this is the profession's official view of itself. If this book is any indication of the wisdom and facility with which libraries are preparing for the advent of the online age, then the future of library services is indeed dim.-Ross Atkinson, Cornell University, Ithaca, New York.

Baum, Christina D. Feminist Thought in American Librarianship. Jefferson, N.C.: McFarland, 1992. 180p. alk. paper, $\$ 28.50$ (ISBN 0-89950-724-7).

Over the past twenty-five years, feminism has made a significant impact on American librarianship, yet very little scholarly attention has been paid to this topic. It clearly merits research and investigation from a variety of perspectives, greater publishing activity, and focused attention in library school curricula. The reader thus approaches Feminist Thought in American Librarianship expectantly, hoping to find in the promise of the title answers to questions that scholars have not asked before. Indeed, Baum might be considered a pioneer for making one of the few attempts to date to "trace the impact of various kinds of feminism on the thought and political agenda of American library women." Unfortunately, her recognition of an area in need of careful and critical research isn't enough; the end result is disappointing on most counts.

The time frame of Baum's book, 19651985 , spans the two decades that marked the emergence of the second wave of feminism in the United States and the increasing involvement of many, including librarians, in the women's move- 
ment. In a brief introductory paragraph, she dismisses out of hand "obtrusive techniques of data gathering such as surveys and interviews," and makes vague and undocumented references to internal debates about the "nature of library feminism" and "defensiveness among library women" in an effort to justify her design of an "empirical, unobtrusive study." She proposes to "test the impact of various kinds of feminism" in three ways: 1) content analysis of literature "about library women by American library women" published during this period (some 250 books and articles); 2) citation analysis of this literature with an aim to classify the feminist authors outside librarianship who have been cited by library women; and 3) content analysis of "all programs devoted to women's issues" at the American Library Association annual meetings during these same two decades.

If this methodology and source material are peculiarly limited given the scope and complexities of her topic, they are further weakened by a lack of sophisticated and informed analysis of the data. The work is replete with vague references, broad assertions, and questionable assumptions (e.g., ". . . many kinds of sex discrimination have been outlawed, and the requirement of affirmative action programs and the legal right to abortion have been established.") The "analysis" presented is confined to a categorization of the literature on "library women" and ALA conference programming as either liberal/mainstream feminist or radical feminist.

Baum argues, accurately albeit simplistically, that liberal feminism strives to integrate women into existing institutions on an equal basis with men, while radical feminism seeks to transform those very institutions. But these arbitrary and problematic categorizations into "liberal/mainstream" or "radical" - as if all feminist activity, let alone all feminist librarians, can be defined and labeled with these very narrow terms - severely restrict the analytical potential of this study. Moreover, Baum fails to define these categories in a way sufficient even to her limited purposes. Among the many vague and contradictory assertions encountered in this work, she places such revolutionary initiatives as comparable worth (efforts extending far beyond liberal equal pay for equal work formulas) in the liberal category and at the same time flatly asserts that "liberal feminists stress transforming social institutions, such as the law, the economy, and the schools, in ways that would liberate women." (italics mine). She seems to trip herself up with a liberal/radical dichotomy which ignores not only other types of feminism (socialist feminism is one notable example) but also the fact that most issues-affirmative action, pay equity, maternity rights (labeled here as liberal) or pornography, homosexuality, sexual harassment, reproductive rights (labeled here as radical)can and should be addressed from multiple theoretical and political frameworks. Librarians have tackled such issues using a variety of approaches, but Baum, firmly entrenched in her arbitrary classification scheme, fails to explore the implications of these efforts. She also fails to recognize the many issues in librarianship that are not neatly categorized as "women's issues" but which have been approached and shaped through librarians' feminist perspectives and activities (such as cataloging and classification practices, bibliographic instruction, and implementation of new technologies).

This work rests on the premise that an uncritical examination of library literature and conference programming will somehow reveal the impact of feminism on American librarianship. For more than twenty years, feminist librarians have brought a variety of philosophical, political, and analytical perspectives to their work in libraries, their publications, and their ALA activities. Lamentably, little analytical acumen is applied to the literature and the programming examined here, resulting in a study that is both shallow and incomplete. If this study provides evidence of anything, it is the limitations of simple content and citation analyses to represent and analyze complex phenomena that elude neat categorization. 
With a more rigorous theoretical and methodological framework and a judicious editorial hand, this project might well have made a notable contribution to the literature and to our understanding of recent developments in American librarianship. As it is, the publisher apparently reproduces here a barely reworked dissertation, acknowledged nowhere in the book. Further, the publisher neglects even the most basic editing of obvious grammar and spelling errors, let alone redundant, disjointed, and simplistic discussions of complex issues. One can only suspect commercial exploitation of a hot topic in the publication of a book whose promising title alone will carry it into many libraries despite its poor quality.

There are enormous potential and need for solid scholarship on this topic. Our profession can only benefit from well-researched, insightful studies of feminism and librarianship and feminist perspectives on librarianship: library applications of feminist critiques of information and knowledge; genderbased values and politics in library workplaces; ways in which feminism informs bibliographic instruction or management or materials selection; library implications of feminist debates around censorship and media, to name just a few potential areas that warrant investigation. In spite of its definitive-sounding title Feminist Thought in American Librarianship skirts the complexities of multiple feminisms and their application within a predominantly female but still male-dominated profession. Readers thus must wait still longer for the authoritative study of the impact of feminism on librarianship that the profession so critically requires.-Joan Ariel, University of California, Irvine.

\section{Australian Studies: Acquisition and} Collection Development for Libraries. Ed. by G. E. Gorman. London: Mansell, 1992. 347p. $\$ 80$. (ISBN 0-72012134-5.)

The Washington Post reported in late November that the Australian government had lifted its ban on homosexuals in the military. This is just one example of the many issues common to both Australia and the United States. Published materials on such issues are of current interest to American readers. As Robert Ross, the director of the Australian Studies Center at the University of Texas, writes in this volume, interest in Australian studies in the United States is growing, albeit gradually. Ross cites the founding in 1978 of the Association of College and Research Libraries's Australian Studies Discussion Group and the 1985 establishment of the American Association of Australian Literary Studies as evidence.

Australian Studies "addresses the needs of librarians charged with collecting and managing collections with an Australian content." The book contains eighteen essays divided into five broad areasDemand for Australian Collections; Australian Publishing; Selecting and Purchasing Australian Publications; Australian Collections (Experience in Three Countries); and Special Needs and their Solution.

This is the only work that brings together information on Australian publishing, selection, and collections. The essays that cover publishing in Australia are especially helpful. Reference librarians can use John Mills's article on reference publishing as a checklist for building a current reference collection on Australia. Michael Harrington's essay on government publishing provides current information about the Australian Government Publishing Service, as well as other government information, including the scientific and technological works published by the Commonwealth Scientific and Industrial Research Organization (CSIRO). Jerelynn Brown provides a summary of useful sources for selecting Australian materials, although this reviewer questions the practice of having an article on selection written by the sales manager of the major Australian book supplier (the article does favor the author's employer, the firm of James Bennett). The article by Ross Atkinson, "Developing an Australian Literature Collection: An American Per- 